\title{
The Experience of Law and Art Literature in the 16th Century: Benvenuto Cellini's La Vita*
}

From the Middle Ages until the start of the modern era, law and texts in the legal tradition were an important source for Italian literature. There are several reasons for this, the principal one being the socio-intellectual nature of legal and literary activities. As we know, men of letters were often also men of the law, and vice versa-from the lawyers at the Court of Frederick II, who were the first to produce Italian literature in Sicily at the beginning of the thirteenth century, to the eighteenth century at least, it was very rare to find literary authors who did not have substantial legal training. At the same time, before the advent of the modern practice of separating disciplinary fields, the theory and practice of literature and that of law were inseparable. Even the history of the intellectual professions and writing customs require us to reconstruct the closeness and complexity of the links between law and literature. For a long time, particularly in France, literary and philosophical studies ignored the judicial culture of their authors, and the work that is today making up for this 'late start' undoubtedly brings new understandings to the law and literature issue.

When one focuses, then, on what literature owes to law, one naturally looks at the learned milieux: the links between jurist-writers and writer-jurists, their respective practices and sources, the judicial sources of literature, and also (although less

Romain Descendre, Ecole Normale Supérieure de Lyon; member of the Institut Universitaire de France; UMR CNRS 5206 'Triangle'. 
often) the literary sources of law. ${ }^{1}$ Nevertheless, if one wishes to appreciate the extent of the presence of law in literature, it may be of interest to seek its traces in authors characterised by a certain marginality, to the extent that they have no legal training and very little literary training either: in other words, authors who can in no sense be counted amongst the 'humanists'. In sixteenth-century Italy, this applied to a whole professional category, the artefici (so not yet, then, artisti). These men of humble origins, whose art was for a long time considered mechanical, came to be considered 'liberal' and the founders of an intellectual profession. Their socio-symbolic conquest found expression in writing which had as its principal purpose the legitimisation of their social advancement. Due to the fact that the writings of Renaissance artists do not belong to the canonical texts of studies on law and literature, they offer a unique opportunity to test the validity of such an approach.

Such is the case with Benvenuto Cellini's La Vita, which was begun in 1558 and came to a premature conclusion in $1567:^{2}$ the law and literature link is tangible in the autobiography of the Florentine goldsmith and sculptor, and yet not only was Cellini a stranger to the legal profession (moreover, as was the case for almost all artists of the period, he had no mastery of Latin), he was also far removed from the literary profession, and was in no way destined to become a writer. Cellini thus constitutes a borderline case for law and literature, two areas he experienced without having either the formal knowledge or the skills for them. In fact, in Cellini's case, the correlation between law and literature is rather unusual: it is that of an artist who takes up the pen out of necessity, following several legal conflicts with his lord, Cosimo I, Duke of Tuscany, and after long periods of attending courts and experiencing prisons.

1 There is much contemporary literature on all these questions, and this volume will add to it. Here I will mention just one journal's issue that concentrates on one of the lesserknown facets of this field of study. Diego Quaglioni's 'La vergine e il diavolo. Letteratura e diritto, letteratura come diritto' in Maurizio Cau and Giuliano Marchetto (eds), Droit et littérature (2004) 5 Laboratoire italien is not concerned merely with law in literature or law as literature, but with literature as a feature of medieval common law, that is, literature in law or literature as law.

2 Benvenuto Cellini, La Vita, E Camesasca (ed) (Rizzoli, 1985). For a useful focus on the recent critical literature see Corinne Lucas Fiorato, 'La genèse douloureuse et la réception difficultueuse des écrits de Benvenuto Cellini' (2009) 5 Seizième Siècle 299-318. 
Piero Calamandrei, one of the most important Italian jurists of the twentieth century and one of the most mindful of the links between law and literature, and a writer himself, was the first to underline the importance of the judicial questions presented in Cellini's La Vita: ${ }^{3}$

Without being a jurist, knowing nothing of the laws of his time, Benvenuto frequently set the law in motion and was the scourge of lawyers and judges; anyone who wishes to study in real life the legal institutions of Cellini's time in Florence, Rome or even Paris has only to follow him in the peregrinations of which his La Vita gives us a lively itinerary, and to see him at every step engaged with criminal court judges, accused of the most serious and dishonourable crimes - from assault and battery to sodomy and including theft and murder-or engaged in bitter and fierce civil proceedings. ${ }^{4}$

In another study, Calamandrei portrays Cellini as a perfect goldsmith of judicial eloquence:

[W]hen he started, he was a fashioner of oratory effects, more skilful than any lawyer. One could cite two or three examples in La Vita of harangues delivered in his own defence in which the legal twists and turns acquire a grace and sinuosity that perfectly brings to mind his goldsmith's work. ${ }^{5}$

3 On Calamandrei, the jurist and writer, see in particular the conference papers Piero Calamandrei tra letteratura, diritto e politica (Vallecchi, 1989) and Paolo Carta, 'Humanisme juridique du XXe siècle' (2004) 5 Laboratoire italien 13-37. Calamandrei had a passion for the work of Cellini, a passion that led him to research the archives and to produce studies that are still today of prime importance to specialists. See Piero Calamandrei, Scritti e inediti celliniani, C Cordié (ed) (La Nuova Italia, 1971).

$4 \quad$ 'Senz'essere giurista, senza intendersi di leggi, Benvenuto ha assai di frequente messo in moto le leggi e ha dato molto da fare ai notai ed ai giudici: e chi voglia studiar sul vivo gli istituti giudiziari del suo tempo a Firenze, o a Roma od anche a Parigi, non deve far altro che accompagnarlo nelle peregrinazioni di cui la Vita ci fornisce un colorito itinerario, per vederlo ad ogni passo alle prese coi giudici penali, sotto le accuse più gravi ed infamanti, dal ferimento al furto, dall'omicidio alla sodomia, ovvero accanito in aspre contese civili di cui sono pieni specialemente gli anni della sua vecchiaia.' P Calamandrei, 'Un contratto di edizione di Benvenuto Cellini' (1930) in Scritti e inediti celliniani (n 3) $39-52,39$.

5 'voleva dire da sé le sue ragioni, e quando ci si metteva, riusciva ad essere, meglio di ogni causidico, un abilissimo cesellatore di artifici oratori. Si potrebbero citare nella Vita due o tre esempi di vere e proprie arringhe avvocatesche da lui pronunciate in propria difesa, nelle quali il cavillo assume una grazia e una flessuosità che proprio fa venire in 
The jurist here alludes to several trial scenes that punctuate the text, in which Benvenuto conducts his own defence with formidable effectiveness. ${ }^{6}$ But what he does not reveal is that Benvenuto's victories in court were not only the fruit of his talent as a litigant - they came above all from the didactic attitude he adopted towards a legal institution which he felt needed to be taught a lesson. It is more as a law professor than as a lawyer that he is successful in the trials, for example explaining to a judge in a Paris court the correct interpretation of French law relating to sodomy, ${ }^{7}$ or giving a lesson on inquisitorial procedure to judges in the Pope's entourage who had accused him of stealing papal treasure, but who, according to him, had not followed the most elementary rules of judicial enquiry. ${ }^{8}$

This affinity with legal material, unusual in a non-jurist, could only have been built up through long experience. Cellini had been mixed up in all manner of criminal affairs and, having exhausted the criminal courts, 'he withdrew from the career of aggressor and murderer, in which he had had much success, to devote himself to a career as litigant'; he thus gave himself 'body and soul to civil causes'. ${ }^{9}$ It is probably not by chance that this transition from the criminal to the civil, which can be dated to the years $1556-7$, coincided with another transition-a transition from 'doing' to 'telling', that is, from sculpture to writing, firstly poetic and then autobiographical writing from 1558. As Cellini himself put it, 'since I was prevented from doing, I started to tell'. ${ }^{10}$

Accustomed to placing Cellini in the long literary tradition of memorial writing hagiographies, lives of famous men, confessions, artists' autobiographies-literary historians have in general placed little emphasis on the legal paradigm underlying

mente i lavori di oreficeria.' P Calamandrei, 'Il Cellini uomo' (1952) in Scritti e inediti celliniani (n 3) 3-35, 12.

La Vita (n 2) bk I, ch 103, 340-4; bk II, ch 30, 474-6.

Ibid, 475.

Ibid, 342.

'Da quell'anno [ie 1556] Benvenuto si ritirò dalla carriera di feritore e di omicida, nella quale aveva raccolto non pochi allori e si dette alla carriera del litigante : abbandonò $\mathrm{i}$ tribunali penali, e si dette tutto, anima e corpo, alle cause civili.' Calamandrei, 'Il Cellini uomo' (n 5) 10.

${ }_{10}$ 'Solo per giovare al mondo, e per essere lasciato da quello scioperato, veduto che m'è impedito il fare, essendo desideroso di render grazie a Dio in qualche modo dell'essere io nato uomo, da poi che m'è impedito di fare così io mi son messo a dire.' B Cellini, Trattato dell'oreficeria, XII, in Opere, Bruno Maier (ed) (Rizzoli, 1968) 718. 
La Vita, even though it is explicitly stated by Cellini,, who never ceased to assert that the aim of his book was to defend his ragioni, that is his rights, and who, in so doing, called for his readers to be positioned 'at a distance and free of passion'. ${ }^{11}$ Whilst Calamandrei drew the attention of specialists to the exceptional historical document that La Vita represents for historians of the civil and criminal law in force in Italy and France in the mid-sixteenth century, he was careful not to interpret the whole book in the light of the judicial theme. However, this book is also the "public justification of numerous legal cases in which [Cellini] was the protagonist', as one art historian has astutely reminded us. ${ }^{12}$ It has been suggested very recently, and convincingly in my opinion, that the memoir of an accused man written for his own defence belongs to a distinctive juridical genre of literature, and that La Vita was modelled on that literary pattern. ${ }^{13}$ In fact, Cellini's autobiography can without doubt be read as a long factum, punctuated throughout by a demand for justice that can certainly seem paradoxical, given the far from edifying crimes and offences with which the book is crammed, but which is no less sincere for all that. ${ }^{14}$ Particularly as the paradox disappears when one realises that all these crimes are in fact acts of vengeance, the legal nature of which must be taken seriously.

Understood as redress, thanks to which the injured party creates his own justice, vengeance was for a long time a common custom recognised by the statutes of Italian communes, particularly those of Florence. ${ }^{15}$ Benvenuto again evolved fully

11 'Questo lo giudichi chi è da canto sanza passione', La Vita (n 2) bk I, ch 79, 278. For the autobiographical genre interpreted in judicial terms, see Gisèle Mathieu Castellani, La scène judiciaire de l'autobiographie (PUF, 1996) from which La Vita is however absent.

12 Giovanna Gaeta Bertelà, in her introduction to the catalogue Benvenuto Cellini. Opere non esposte e documenti notarili, Dario Trento (ed) (Museo Nazionale del Bargello, Florence, 1984), a work that has not been widely distributed.

13 Matteo Residori, 'Le ragioni di Benvenuto. Giustizia e retorica giudiziaria nella Vita di Cellini' (2009) 16(4) Chroniques italiennes, internet series, http://chroniquesitaliennes.univ-paris3.fr/numeros/Web16.html.

$14 \quad$ Romain Descendre, 'Gli uomini come Benvenuto non hanno da essere ubrigati alla legge. Art, droit et politique dans la Vita de Cellini' (2009) 16(4) Chroniques italiennes, internet series, http://chroniquesitaliennes.univ-paris3.fr/numeros/Web16.html; in this article I engage in the same reflections as those pursued here.

15 U Dorini, 'La vendetta privata ai tempi di Dante' (1933) 29 Giornale dantesco 105; AM Enriques Agnoletti, 'La vendetta nella vita e nella legislazione fiorentina' (1933) 91 Archivio storico italiano 85, 181-223; Stefano Andres, 'Oltre lo statuto. La vendetta nella letteratura toscana del Due-Trecento' (2004) 5 Laboratoire italien 57. 
in this world, where for him it was constantly a matter of exacting retribution for the injury received, l'ingiuria, a term to which it is useful to give its legal etymological meaning: it is that which is committed contra ius. However, he came up against the authorities in power in the new Duchy of Tuscany. They had devoted much time and energy to developing an effective criminal justice system, and were unusually active in setting up a system aimed at regulation through centralised law - that is, through the expression of the sovereign's will. Previously there had for many years been a fundamentally pluralistic juridical order, which left plenty of space for the private settling of disputes. So the narrative structure of La Vita describes a process, which had thus become necessary, of moving beyond violence; this process did not break the vicious circle of insult and reprisal, but transformed physical vengeance into symbolic vengeance. ${ }^{16}$ When, within the text, the principal character-narrator renounces violence, he explicitly states that henceforth his vengeance will be his work: thus we see the transition from a system of vindictive action to a metaphorical and symbolic vindictive system, which becomes the perspective of the writing in La Vita. The book itself, from this point of view, is not only a factum with defensive intent, it is also an accusation and vengeance, as witnessed by the very unflattering portrait that Cellini paints of Cosimo I. It is, moreover, the reason why, unfit to be published, it remains unfinished, ${ }^{17}$ the writing having been interrupted when the conflicts that pitted Cellini against Cosimo eased.

The interest to be found in La Vita for a law and literature approach thus lies in the specific closeness of the link that the work maintains between the two terms. For Cellini, who was not a man of letters, and who, unlike his colleague Vasari for example, did not have the support that would allow him to become a writer in the fullest sense, writing was not a choice but a necessity. For him, literature is in a way a continuation of the judicial by other means. There is in his book continuity and contiguity between law and literature, and not just the literary use of judicial material. In it literature is, in the fullest sense, justification and legitimisation.

\footnotetext{
$16 \quad$ For more detail see Descendre (n 14).

17 This is also why the author later untruthfully maintained that he had destroyed the sections concerning his relationship with the Prince, in the lines that precede the passage of the Trattato dell'oreficeria (n 10).
} 
This legitimating function appears most strongly when the status of the artist is defined by the special relation that he must be free to maintain with the law. One phrase in the book is revealing; it is the words spoken by Pope Paul III to justify the safe conduct that he grants to Benvenuto while the latter is being sought for the killing of one of his rivals: 'You should know that men like Benvenuto, who are unique in their profession, are not bound by the law' (Sappiate che gli uomini come Benvenuto, unici nella lor professione, non hanno da essere ubrigati alla legge). ${ }^{18}$ With this papal utterance, Cellini sets out to establish both his rights and his exceptionality in terms that belong solely to the language of general public law (that is to say the public law aspects of the ius commune). In fact, it is not so much the justification of behaviour considered unlawful that is set out here, as the institution of a special set of rules defining sovereignty in one's own right. This formula is nothing less than a paraphrase of one of the most famous maxims of the Digest, Ulpian's words princeps legibus solutus est-'the prince is absolved from laws, he is not bound by the laws ${ }^{19}$ - which jurists, from the time of the glossators, used to define the absolutist aspect of sovereignty. As we know, the insistence on absolutio legibus became stronger still in the sixteenth century, to the detriment of the opposite principle, princeps legibus alligatus, not only in the juridico-political doctrines that came with the birth of absolutism, but also in the common language of the chancelleries and courts. Moreover, it is probably not by chance that the new usage suggested by Cellini, to the benefit of the artist, issues from the mouth of a Pope, for it is true that it was at Rome, with the canon law theory of the plenitudo potestatis of Popes, that the absolutist principle was first vigorously defended. ${ }^{20}$

Cellini used the language of law to establish his status as sovereign artist, which put him on a continuously asserted equal footing with princes. ${ }^{21} \mathrm{We}$ thus find that

\footnotetext{
$18 \quad$ La Vita (n 2) bk I, ch 74, 265.

19 Digest, 1, 3, 31.

20 For all these questions, see in particular Ennio Cortese, La norma giuridica. Spunti teorici nel diritto comune classico, vol 2 (Giuffré, 1964); Ennio Cortese, 'Sovranità (storia)' in Enciclopedia del diritto, XLIII (Giuffré, 1990) 205; Diego Quaglioni, La sovranità (Laterza, 2004).

$21 \quad$ There are many passages where Cellini sets out this presumed equality with sovereigns, as with Francis I of France for example, with whom he used the familiar 'tu'
} 
Cellini's work validates the thesis put forward by Ernst Kantorowicz in one of his last articles, written in honour of Erwin Panofsky, 'The Sovereignty of the Artist'. ${ }^{22}$ What Kantorowicz claimed at a scholarly level-namely 'that the writings of medieval jurists, glossators and commentators of roman and canon law, might have been in any respect relevant to the development of Renaissance theories of art', and 'that certain current views had been foreshadowed by the writings of the jurists ${ }^{23}$ - finds confirmation within the oral culture of the princely courts as it is documented by the written work of an artist who regularly attended them. Jurists in particular had to resolve a whole series of problems linked to terms that were fundamental to juridical science, ars, natura, imitatio, inventio, fictio, veritas. The ars - that is, the law-must imitate nature through the intermediary of a fiction, that is, an invention. From this fact, as a law-maker, the prince was in a position to be seen as a re-creator of nature, and to be compared with the divine creator, sicut deus in terris. It was first in canon law and around the figure of the Pope that such ideas were expounded, particularly by the decretalists at the beginning of the thirteenth century, who developed most fully the theory of potestas plena. Thus, around 1220 the canonist Tancred elucidated Innocent III's idea according to which the Pope is the 'vice-gerent of God', stating that 'he makes something out of nothing like God'. ${ }^{24}$ The theories of plenitudo potestatis invented the figure of the divine creator who, several centuries later, played a decisive role in art literature, whether one thinks of Leonardo da Vinci's Libro di pittura (the 'signore e Dio' painter capable of creating everything ${ }^{25}$ ), Michelangelo, the divine artist glorified particularly by Vasari, or Cellini, who presented the casting of his Perseus as a supernatural creation resulting in a true resurrection. ${ }^{26}$ Therefore,

form of address and called him, in French, 'my friend'. Conversely, he never hesitated, on several occasions, to lecture the Pope or treat him insolently.

22 Ernst H Kantorowicz, 'The Sovereignty of the Artist: A Note on Legal Maxims in Renaissance Theories of Art' in De Artibus opuscola XL: Essays in Honor of Erwin Panofsky, Millard Meiss (ed) (New York University Press, 1961) 267 (subsequently reworked in EH Kantorowicz, Selected Studies, M Cherniavsky and Ralph E Giesey (eds) (JJ Augustin, 1965) 352.

$23 \quad$ Ibid, 267-8.

$24 \quad$ Ibid, 271-2.

25 Leonardo da Vinci, Libro di pittura, C Pedretti and C Vecce (eds) (Giunti, 1995) 138 [13].

26. La Vita (n 2) bk II, ch 77, 571-2. 
there is nothing strange in the fact that a formula such as princeps legibus solutus should be the background to Cellini's claim of not being 'bound by the law' (ubrigato alla legge) and that he should make use of a Pope to defend it. ${ }^{27}$

It is clear that Cellini's legal culture did not come from a scholarly knowledge of written law and the ius commune legal tradition. However, we would be wrong, today, to think that such a culture was inaccessible to a goldsmith: Lucien Febvre and Henri-Jean Martin had stressed that a large number of the law books that constituted the greatest part of the libraries of the French in the 16th century belonged to "men whom one would imagine being indifferent to these specialities - goldsmiths, millers, apothecaries, for example" ${ }^{28}$. But it is even more significant that Cellini had in his close entourage people such as Benedetto Varchi, the official historian of Florence and a lawyer by training, and Lelio Torelli, Cosimo I's First Secretary, who was at that time the principal representative of Florentine legal humanism. ${ }^{29}$ But ultimately the artist's entourage does not really matter. It is the linguistic dimension of law, its communal character, and thus the possibility that it can nurture a narrative, that appears in the re-uses and adaptations that he works on for his own benefit. Whether it is the numerous legal proceedings that are emphasised in the autobiography, the judicial model as background to the writing and the genre of the book, or even the linguistic tools borrowed from academic law with the aim of establishing the artist's sovereignty, everything relates to legal matters and derives from first-hand experience, and that says much about the central place occupied by law in the society of the time.

Within the context of a more general enquiry into the reasons for a linking of law and literature, and in order to project a wider view on the specific case of Cellini, I

$27 \quad$ For an analysis of the role played by other elements of medieval legal heritage in La Vita, and in particular the question of tyranny, which he uses to take a critical look at both the actions of princes and the false hopes of exiled Florentine republicans, see Descendre (n 14).

${ }^{28}$ Lucien Febvre and Henri-Jean Martin, L'apparition du livre (Albin Michel, 1999) (1st edn 1958), 391.

$29 \quad$ Primo Secretario and Primo Auditore of Cosmo I, and head of the Duchy's new administration, Lelio Torelli was one of the most powerful men in the Tuscan state. He was also the author of the princeps edition of the Florentine Manuscript of the Pandects (one of the most precious manuscripts of Justinian's Digest): he published it in 1553 with the printer Lorenzo Torrentino, who had been brought from the Duchy of Brabant to act as the Duke's official printer. He became a close friend of Cellini; as his executor from 1555, Torelli asked Cosimo to release him from prison the following year. 
will conclude my paper with two short remarks, concerning the question of what each of these fields can bring to the other. On what law can add to the understanding of literature: to dispense with it simply means, in many cases, being unable to understand either the motivation for a piece of writing or the specific form that it takes, including that of some authors from outside the world of the jurists (this is particularly relevant when the authors studied have had legal training and practised law, as was shown in the enlightened reading of Montaigne by André Tournon, or more recently still, that of Guicciardini by Paolo Carta). ${ }^{30}$

On the other side of the equation, that is, what literature can bring to the understanding of law: Cellini gives us much more, I believe, than a lively portrait of judicial practices in Italy and France in the mid-sixteenth century-even if, on this subject, the analysis formulated by Calamandrei remains highly relevant. The author of La Vita reveals to us the extent to which law could be embedded in people's lives, how it could support their vision of the world and their place in it, could constitute the very order of human reality, and thus become part of life for an individual who was anything but a jurist. This is a lesson that is still significant today at a time when, for ordinary people, law is often a coded language, an inaccessible field of knowledge. For me, perhaps a little naively, this is a way of rediscovering a reality of law that is not reduced to the rules desired by the lawmaker and thus does not appear to be, or not only to be, an instrument of political domination.

\section{Romain DESCENDRE}

$30 \quad$ André Tournon, Montaigne, la glose et l'essai (Champion, 2000) (1st edn 1983); Paolo Carta, Francesco Guicciardini tra diritto e politica (Cedam, 2008). 